\title{
Legal Protection of Housing Consumers Relating to the Cancellation of Building Permits
}

\author{
Zulki Zulkifli Noor ${ }^{1} \& J^{2}$ aya Jaya ${ }^{1}$ \\ ${ }^{1}$ Unversitas Jayabaya, Indonesia \\ Correspondence: Zulki Zulkifli Noor, Unversitas Jayabaya, Indonesia. E-mail: ake_zulkifli@yahoo.com
}

Received: October 12, 2019

Accepted: January 3, $2020 \quad$ Online Published: January 9, 2020

doi:10.5539/jpl.v13n1p29

URL: https://doi.org/10.5539/jpl.v13n1p29

\begin{abstract}
The main goal of study is investigating the procedure for the issuance of Building Permit (BCP) for housing which they are expressly regulated in the provisions of the applicable legislation. In this vein, BCP must first be met formal and material requirements and then pay attention to technical and non-technical aspects before the taking the development process. However, in its implementation, BCPs were still being issued without regard to the provisions requirements of he prevailing laws and regulations. The problem discussed in this study is to study the legal consequences of the cancellation of Building Permit (BCP) on the house purchase agreement and compensating the void and null between the developer and the consumer by implementing the legal protection against consumers.
\end{abstract}

Keywords: Building Construction Permit (BCP), Purchase Binding Agreement (PBA), cancellation, consumer protection

\section{Introduction}

Implementation and development in the housing sector aims to fulfill the rights of citizens to adequate housing in a healthy, safe, harmonious and orderly environment and to ensure the certainty of settling, which must be carried out in accordance with the direction of the development of residential areas, giving direction to the growth of the region, expanding the field work and drive economic activities in the context of increasing and equitable distribution of the welfare of all Indonesian people. Without a house or proper place of residence, a person's existence is formally difficult to recognize, so that the house is an entrance to a world that promises fulfillment other basic needs, even the general housing situation is often considered a barometer of a nation's standard of living. ${ }^{1}$

The arrangement of housing and settlement areas is carried out to provide legal certainty in the administration of housing and settlement areas, supporting regional arrangement and development as well as proportional distribution of population through the growth of residential and residential areas in accordance with spatial planning to create a balance of interests. The organizer of housing construction and residential areas to meet the needs of housing, the implementation can be carried out by the government, local government, and or each person. According to Article 1 number 25 of Law Number 1 of 2011 concerning Housing and Settlement Areas, what is meant by every person is an individual or legal entity. Requirements that must be met in the implementation of housing and settlement area development by both the government and the private sector are about Licensing. There are eight Permits that must be fulfilled, namely: Local Environmental Permit; Information on the General Spatial Plan (RUTR); Land Use Permit; Principle permit; Location permission; Permit from the Environment (BLH) or Environmental Impact Analysis (EIA); Traffic Impact Permit; Ratification of the site plan. ${ }^{2}$

Allegedly in some cases housing development by the private sector is found to be incomplete licensing, but the developers have dared to market through promotional brochures, because in recent years housing development by the private sector has caused very tight competition in attracting buyers. The impact is a practical and fast way to sell property in the form of offices, housing and apartments by developers, especially by the marketing

\footnotetext{
${ }^{1}$ Marsono, Laws and Regulations in the Field of Housing and Settlements, Jakarta, Djambat, 1995, page. 12.

${ }^{2}$ Regulation of the Minister of Public Works and Public Housing of the Republic of Indonesia, Number 24 / PRT / M / 2007 Regarding Technical Guidelines for Establishing Buildings.
} 
division (marketing), known as the preprojectselling system. This marketing concept is becoming a trend at this time, especially for developers of residential projects (developers) usually done by the developer by selling or marketing before the relevant property product is realized, there are even project developers who do the concept of pre-marketing marketing before completing the requirements, among others Building Construction (BCP), Construction permits and other permits.

Developers who intend to launch their projects, must have all the required permits and postpone the licenses referred to if the developer continues to do marketing (pre-projectsales) before meeting administrative requirements. The attractiveness of the concept of preproject marketing is very large when viewed from the flock of consumers or people who visit prelaunching or pro sale events and this kind. Usually prospective customers are tempted by discounts of $20 \%$ to $30 \%$ provided by the developer, in addition to the discounted prices are also given a bonus of electronic equipment which amounts to millions of rupiah even up to tens of millions of rupiah. ${ }^{3}$

It is related to the business strategy used by these business actors that often causes losses for consumers. In the Consumer Protection Act (UUPK), among others, it is emphasized, business actors are obliged to guarantee the quality of goods and or services produced by funds or traded based on the provisions of the quality standards of fund goods or services in force. Business actors are prohibited from producing funds or trading goods or services that do not meet or do not meet the required standards. These provisions should be obeyed and implemented by business actors. However, the reality is that many business actors lack or do not pay serious attention to these obligations or prohibitions, thus impacting on problems with consumers. One of the problems referred to is the cancellation of one of the permits owned by the housing, namely Building Permit (BCP), while the cancellation of the BCP was experienced by Podomoro City Deli Housing under the management of PT. Sinar Menara Deli which was canceled through the Supreme Court Decree Number 274 K / TUN / 2016 dated August 11, 2016, even though some of the houses that have been built on the housing have been sold to consumers through a Sales Binding Agreement (PBA), the result of the cancellation of the BCP raises the potential losses suffered by consumers who have purchased housing units at the Pomomoro City Deli housing complex.

Based on the explanation, it is necessary to further discuss the consequences of the cancellation of $\mathrm{BCP}$ on the sale and purchase through PBA between Podomoro City Deli Housing Developers and consumers, as well as how legal remedies in this case are legal protections for consumers who feel disadvantaged due to the cancellation of the BCP.

\subsection{Identification of Problems}

Based on the description in the background above, the Problem Identification can be formulated as follows:

a. What are the legal consequences of canceling a Building Permit (BCP) on a home purchase agreement between a developer and a consumer?

b. How is the implementation of legal protection against consumers in the case of a sale and purchase agreement null and void?

\section{Research Objectives}

The objectives of this study include:

a. To find out and examine the legal consequences of the cancellation of Building Permit (BCP) on a home purchase agreement between the developer and the consumer.

b. To find out and examine the implementation of legal protection against consumers in the case of a sale and purchase agreement null and void by law.

\section{Research Methods}

The research method is very important in order to obtain accurate research results, therefore researchers conducted the method of approach used in this research is normative juridical research, which is research that includes the study of legal principles, legal systematics, synchronization of vertical and horizontal laws. In normative juridical research, prioritizing how to examine library materials or so-called secondary data materials, forms positive law and how it is implemented in practice. ${ }^{4}$ Literature data obtained in the form of positive law, a collection of various statutory provisions in force in Indonesia today.

The library data is then used in solving problems that exist in research conducted by researchers. Normative

\footnotetext{
${ }^{3}$ Data from www.rei.or.id, Pre Project Selling, accessed on March 5, 2018, 12.00 WIB.

${ }^{4}$ Bambang Waluyo, Legal Research in Practice, Jakarta, Sinar Grafika, 1991, page. 17.
} 
juridical study is carried out on the principles or principles of law related science. The approach used in this research is the law approach. Statute approach is carried out by examining all laws and regulations relating to the legal issues being handled in analyzing the case of Building Permit (BCP) which must canceled because it does not have an EIA (Case Study of the Supreme Court's Decision Number 274 K / TUN / 2016).

\section{Discussion}

\subsection{Legal Consequences of Cancellation of Building Construction Permit (BCP) on Housing Purchase Binding Agreement (PBA) between Developer and Consumer}

Issuance of Permit Documents that are closely related to permits have a legal rule or have their own legal basis, Permit documents are issued which are based on the rule of law not only for short-term interests, but must be based on long-term interests, one of which is a Building Permit ( BCP). Various statutory provisions governing the $\mathrm{BCP}$ also regulate the requirements for obtaining a building permit, there are sanctions, benefits and objectives as well as the provisions regarding the revocation or revocation of the permit.

Concerning Cancellation, in this case the cancellation of Building Permit (BCP) is generally carried out by the authorized regional government such as the regional head of the Regent or Mayor, from the legal aspect the meaning of cancellation is to contain two kinds of possible reasons, namely, cancellation because it does not meet the subjective requirements and cancellation because of default from the debtor. Cancellation can be done with 3 conditions, namely, the agreement must be reciprocal (bilateral), there must be a default (breach of contract), must be with the verdict of the judge (verdict).

Based on the results of the study note that the cancellation of Building Permit (BCP) caused by irregularities contained in the $\mathrm{BCP}$ issuance process for Podomoro City housing located in Medan City, there are indications that the Podomoro City housing complex does not yet have an Environmental Impact Assessment (AMDAL) which is one of the administrative requirements for the issuance of BCP, therefore Citra Citra Justice Foundation (YCK) which is one of the Non-Governmental Organizations (NGOs) engaged in the field of The environment in the name of the community is suing the Podomoro Deli City licensing on the grounds that the construction of the Podomoro Deli city has a negative impact on the environment such as TVRI broadcasts in Medan Station, Deli Watershed (DAS), and violates the Building Border Line (GSB).

The lawsuit process filed by YCK in connection with the issuance of BCP Podomoro Deli City was carried out against the Mayor of Medan as defendant I and PT. Sinar Menara Deli as defendant II through the Medan State Administrative Court (PTUN), at that time PTUN granted the suit, while the decision number was 26 / G / 2015 / PTUN-MDN dated October 28, 2015. But the Medan City Government appealed to The Medan State Administrative High Court (PT TUN) and won by reason of the YCK legal entity being inappropriate, then YCK appealed to the Supreme Court which was registered on June 7, 2016 and the Supreme Court granted the Citra Justice Foundation appeal regarding the Podomoro Deli City licensing, while the decision number is $274 \mathrm{~K} /$ TUN / 2016 dated 11 August 2016. The Supreme Court granted the Citra Justice Foundation appeal to cancel the BCP for the construction of the Medan Podomoro Deli City Mega Project and the absence of an environmental permit resulted in all licensing of Podomoro Deli City being null and void by law making it obligatory The Mayor of Medan canceled the Building Construction Permit (BCP), as well as Podomoro Del i City and demolished and demolished the Podomoro Deli City project. With the ruling to grant the plaintiff's claim for all; Declared the Decree of Medan Mayor No. 645 / 299.K Regarding Building Permit dated March 24, 2015 on behalf of. PT. Sinar Menara Deli; Require the Defendant to revoke: Medan Mayor Decree No. 645 / 299.K Regarding Building Permit dated March 24, 2015 on behalf of PT. Sinar Menara Deli; Punish Defendant and Defendant II Intervention to pay the cost of the case jointly in this dispute amounting to Rp. 950,000, - (Nine Hundred Fifty Thousand Rupiah).

The decision was based on consideration in the provisions of the Regulation of the Minister of Public Works and Public Housing of the Republic of Indonesia, Number 24 / PRT / M / 2007 Regarding Technical Guidelines for Constructing Buildings that require a Permit from the Environment (BLH) or Environmental Impact Analysis (EIA) ) as one of the absolute requirements for the issuance of BCP. ${ }^{5}$

As a result of the absence of an Environmental Permit (BLH) or Environmental Impact Analysis (AMDAL)

\footnotetext{
${ }^{5}$ Regulation of the Minister of Public Works and Public Housing of the Republic of Indonesia, Number 24 / PRT / M / 2007 Regarding Technical Guidelines for Establishing Buildings. The requirements that must be met in the implementation of housing and settlement development by both the government and the private sector are Licensing. There are eight Permits that must be fulfilled, namely: Local Environmental Permit; Information on the General Spatial Plan (RUTR); Land Use Permit; Principle permit; Location permission; Permit from the Environment (BLH) or Environmental Impact Analysis (EIA); Traffic Impact Permit; Ratification of the site plan
} 
causes harm to the surrounding community, the environment and state finances, because an AMDAL is a study of the large and important impacts of a planned business and / or activity on the environment for the decision making process regarding the conduct of businesses and / or activities. $^{6}$

As a result of the Supreme Court's Decision Number 274 K / TUN / 2016 dated August 11, 2016 that canceled the BCP of Podomoro Deli City housing, it greatly affected the continuity of development and has the potential to cause harm to consumers who have entered into a Purchase Bond with the developer, in this case PT. Sinar Menara Deli through Binding of Selling and Purchasing (PBA), PBA in the focus of this research is PBA land and buildings (Houses) made between PT. Sinar Menara Deli (Developer) as the Seller and the Consumers as the Purchaser, which can be made if it has fulfilled several requirements, namely the status of land ownership, the things agreed upon, the fulfillment of the permit, one of which is a Building Permit (BCP).

Please note that the PBA is an aid agreement that functions as a preliminary agreement and is free. The free form of this agreement is based on the principle of freedom of contract, which is regulated in Article 1338 Paragraphs (1), (2) and (3) of the Civil Code which confirms that "All agreements made legally apply as a law to those who make them. The agreements cannot be withdrawn other than by agreement of the two parties or for reasons which are stated by law to be sufficient. Agreements must be carried out in good faith. "These provisions indicate the freedom for everyone to make agreements with anyone and about anything, as long as it is not prohibited by law, applies as a law if it is not contrary to the law, public order, and decency. If it conflicts, then the agreement can be canceled or null and void by law, and the Agreement cannot be withdrawn other than by agreement of the parties.

In addition to the provisions of Article 1338 of the Civil Code, the principle of freedom of contract must also comply with the provisions of the legal conditions of the agreement provided for in Article 1320 of the Civil Code. Fulfillment of legal requirements in the agreement as stipulated in Article 1320 of the Civil Code is an absolute requirement for the occurrence of an agreement, the four conditions above are compulsive provisions (dwingend recht, mandatory law), which if not fulfilled may result in the agreement may or may not be valid.

In connection with the legal requirements of the agreement in PBA which is the focus of research, made between the Developer and the Consumer, it is known that the word "Agree" those who bind themselves, in this case the word "agreed" between the Developer as the Seller and Consumer as the Buyer. is an essential factor that animates the agreement, the agreement is usually expressed with the word "agree / agree" accompanied by the signing of both the Developer and the Consumer as proof of agreement on everything contained in the agreement. With the enactment of the agreement to be one of the terms of the agreement, it means that both parties have freedom of will. The parties concerned did not receive any pressure which would cause the agreement to be defective. The definition of agreement can be explained as a statement of will agreed by the parties. In connection with the terms of their binding agreement, Article 1321 of the Civil Code lists several things that become factors in an agreement being flawed, namely oversight, coercion and fraud. In an agreement an agreement is declared invalid, if the agreement reached is due to negligence or is made by an act of coercion or fraud, which needs to be underlined is the word fraud, bearing in mind when the developer markets his land and buildings to consumers, does he promise that the land against the land is already fulfilled all the requirements, permits and legality, although in the end based on the Decision of the Supreme Court Number 274 K / TUN / 2016 the Building Permit (BCP) was canceled.

The ability to make an agreement, both the ability of the Developer as the Seller, namely PT. Sinar Permata Deli Podomoro as the bearer, as well as the ability of consumers as the buyer of Podomoro Deli City housing managed by PT. Sinar Permata Deli Podomoro.In terms of skills related to the making of PBA between the developers of PT. Sinar Permata Deli Podomoro as a seller with consumers as buyers, it appears that both are legal subjects, PT. Sinar Permata Deli Podomoro as a legal entity legal entity (legal entity) and generally the consumer is an individual legal subject, so that both according to the law can be said capable or have a legal position to make an agreement. This can be seen that both consumers as buyers and those who represent PT. Sinar Permata Deli Podomoro as a seller is a person who is said to have grown up, that is, a person who is 18 years of age or older. In addition to the skills determined that there is authority to act on behalf of a legal entity, in this case someone representing the developer. Based on the results of the study note that the Developer is a business entity incorporated as a Limited Liability Company PT. Sinar Permata Deli Podomoro, which is a legal subject that can carry out the construction of housing and residential areas. In its implementation, it is

\footnotetext{
${ }^{6}$ Article 1 Government Regulation of the Republic of Indonesia Number 27 of 1999 concerning Environmental Impact Analysis

${ }^{7}$ Article 42 of Law Number 1 of 2011 concerning Housing and Settlement Areas: "that houses which are still under construction can be marketed through a system of binding purchase agreement (PBA)."
} 
represented by a person who is authorized or directors of a Limited Liability Company that has obtained approval from the Board of Commissioners and the General Meeting of Shareholders (GMS).

A certain thing means no other than the agreement itself, where in an agreement, the object of the agreement must be firm and clear. In various literatures it is stated that the object of the agreement is the achievement or the main agreement. A thing or object in an agreement must be certain, at least the number and type can be determined. Can be in the form of objects that now exist and will later exist, in this case Land and Buildings which are objects (a certain thing) in PBA that are made between Developers and Consumers. Related to permits, the focus of this research is the Establishment Permit Building (BCP), although not explicitly stated in the PBA, the existence of the BCP is an element of naturalia ${ }^{8}$ contained in the PBA itself, bearing in mind the provisions concerning $\mathrm{BCP}$ as one of the conditions before the PBA is made strictly regulated in various applicable laws and regulations.

Related to a halal reason that each Agreement requires good faith from the parties to the agreement, therefore an agreement caused by something that is not lawful, for example because of coercion or guile does not qualify as an agreement. Lawmakers have the view that agreements may also be held without cause or made for any reason that is false or prohibited. The purpose of a prohibited cause is a cause prohibited by law or contrary to decency either public order as affirmed in the provisions of Article 1337 of the Civil Code, so based on the provisions of Article 1335 of the Civil Code Agreements made with such causes have no power, as well as the revocation of the BCP made by PT. Sinar Permata Deli Podomoro based on the Supreme Court Decision Number 274 K / TUN / 2016, all PBA related to the requirement to have a BCP will be null and void, because the cancellation of the BCP makes the object of buying and selling in PBA included in the category of objects / causes Not permitted.

If reviewed about the substance of PBA made between PT. Sinar Permata Deli Podomoro as a seller with its consumers as buyers first needs to be elaborated on some elements contained in the agreement and is associated with the PBA subscriptions made, because the PBA is an authentic deed made before a Notary Public as a public official, so the form must also meet the applicable laws and regulations, namely Law Number 2 of 2014 concerning Amendments to Law Number 30 of 2004 concerning the position of Notary Public (UUJN). Therefore, if you see the provisions of Article 38 of the UUJN, the PBA must still fulfill the form of an authentic deed. which consists of the beginning of the deed, the deed body and the end or closing of the deed as mandated by UUJN.

The beginning of the deed which contains the Title of the agreement, generally every deed made by a notary regarding PBA is always given the title "AGREEMENT OF BUYING BINDING." Regarding the deed number is determined separately by the notary based on the deed arrangement number made by the notary in accordance with the notary deed repertory book, which phenomena done based on calculations in 1 (one) month starting from the number 1 (one) on each deed he made. Regarding hours, days, dates, months and years must be listed in accordance with the implementation of the signing of the deed by the developer as the seller, the consumer as a buyer, notary and witnesses. In addition to what is required by UUJN to include the title of the deed, the deed number, and the time regarding the deed making, at the beginning of the PBA deed must also include the Full Name and Position of the Notary, based on the results of the PBA research made by Notary X domiciled in the City of Medan and having territory the work covers the whole of the Province of North Sumatra, because this affects the authenticity of the PBA deed.'

The deed body in the PBA as outlined in an authentic form based on UUJN includes the complete identity of the parties, namely someone representing PT. Sinar Permata Deli Podomoro, in this case represented by the Marketing Manager based on the power of attorney obtained by the Board of Directors based on the approval of the General Meeting of Shareholders (GMS) of PT. Sinar Permata Deli Podomoro, and Individual Consumers as buyers, as well as the position of acting for each party in the agreement, this is in accordance with the provisions of Article 39 of the UUJN that confronts the Marketing Manager as a party representing PT. Sinar Permata Deli Podomoro is more than 18 years old, and in general the consumers as the buyer are more than 18 years old. Both the Marketing Manager of PT. Sinar Permata Deli Podomoro and consumers must be known in advance by the Notary in the sense of having to introduce themselves to the notary public. Facing the notary at least among the parties both PT. Marketing Manager Sinar Permata Deli Podomoro and consumers there is an introduction to a notary like what is meant by the article.

\footnotetext{
${ }^{8}$ The Naturalia element, is an element that is not explicitly stated in a contract, but exists and is considered to exist by the parties, is an innate character (natuur) because it has been regulated by legislation.

${ }^{9}$ Preliminary deed of BUYING BINDING AGREEMENT for Podomoro Deli City housing.
} 
The contents of the deed is the will and desire of the parties concerned in the form of agreements that include the scope of the sale and purchase agreement, the rights and obligations of both the Marketing Manager of PT. Sinar Permata Deli Podomoro and consumers as buyers. Regarding the provisions of sanctions, dispute resolution, and other provisions agreed upon by the parties must also be included in the contents of the deed. Because in making an authentic deed regarding PBA a notary is required to pay attention to the elements that must be contained in an agreement, namely:

1) The Essentialia element that gave birth to the Sale and Purchase agreement itself.

2) Naturalis element, is an element that is not stated explicitly in the PBA

3) The accidental element is an element that arises based on a firm promise

Based on the discussion of the results of the study it appears that in the making of the PBA between PT. Sinar Permata Deli Podomoro as a seller with a consumer as a buyer has fulfilled the provisions in the procedure for making an authentic deed regulated in UUJN, because if it is not fulfilled then the PBA only has the power of proof as a deed under the hand.

PBA original deed between PT. Sinar Permata Deli Podomoro as a seller with consumers as buyers poured into authentic deeds called minuta deeds which are used as one of the notary protocols, these minutes become State archives which must be kept and maintained properly by the notary concerned, to the parties, namely PT. Sinar Permata Deli Podomoro as both seller and consumer as buyer is given an original copy of the minutes of the PBA deed to be used as authentic evidence in the event of a dispute in the future resulting from denial of the agreement made by both parties. Because the original copy of an authentic deed can be used as evidence that has perfect proofing power.

Based on the discussion above, it is known that the BCP which is an absolute requirement to make PBA as regulated by several statutory provisions is the object of the agreement that falls into the category of natural elements, so that due to the cancellation of the BCP based on the Decision of the Supreme Court Number 274 K / TUN / 2016 all PBA related to BCP which are supposed to be an integral part of the land and building shall be null and void due to violation of the objective elements / conditions for the legality of the agreement as stipulated in the provisions of Article 1320 of the Civil Code, namely violation of the provisions of "certain things" and the provisions "Halal causes". Because based on Article 1337 of the Civil Code in a contraries it can be concluded that what is meant by halal is that the agreement in this case the PBA is not prohibited by law, decency, or public order. Thus the legal reason as a condition for the validity of the agreement means that the objectives to be achieved by the parties in the PBA must not be contrary to the law, decency, or public order.

In addition to the $\mathrm{BCP}$ cancellation case that occurred in the Podomoro Deli City mentioned above, one of the other cases that has been investigated by the author is used as a comparison for the $\mathrm{BCP}$ cancellation case above, namely the cancellation / revocation of the BCP carried out unilaterally by the Deli Serdang Regency Regent on the grounds reasons which are not appropriate and do not follow the regulations in accordance with the Regional Regulation made by the Regent himself in Case Study of Decision No. 30 / B / 2012 / PT.TUN.Mdn.

According to the provisions of Article 4 paragraph (1) of Regional Regulation of Deli Serdang Regency Number 14 Year 2006 Concerning Permits to Establish Buildings in Deli Serdang Regency, "every individual or body that constructs buildings in the area must obtain a permit from the Regional Head by first obtaining a permit, ${ }^{10}$ based on the provisions of Article 9 of the Regional Regulation it is confirmed that "Building Permits may be revoked by the Regional Head, if they violate the permit conditions granted or later it is known that one or several conditions for obtaining the Building Permit referred to are not true of their validity and / or other matters according to the Head Regions worth considering ". ${ }^{11}$

Every person, legal entity or business entity, group of people and institutions or organizations applying for a Building Permit (BCP) to the Regional Government is referred to as the Petitioner and for building special function buildings to the Regional Government. ${ }^{12}$ Furthermore, Building Permit (BCP) can be processed and issued if the requirements have been met by the $\mathrm{BCP}$ applicant in accordance with the requirements determined

\footnotetext{
${ }^{10}$ Regional Regulation of Deli Serdang Regency Number 14 Year 2006, concerning Permit to Establish Buildings in Deli Serdang Regency, article 4 paragraph (1)

${ }^{11}$ Deli Serdang Regency Regulation Number 14 Year 2006, Regarding Building Permit In Deli Serdang Regency, Article 9 BCP may be revoked by the Regional Head if it violates the permit provision or later it is known that one or several conditions to obtain the Building Construction Permit is not its validity and or other matters according to the Regional Head are worthy of consideration

${ }^{12}$ Article 1 paragraph (5), Minister of Home Affairs of the Republic of Indonesia, Rule Number 32 of 2010, Regarding Guidelines for Granting a Building Permit.
} 
by the Regional Government. In line with these regulations Nurbaya Sianipar as an individual subject on April 5, 2011 filed an application for the issuance of BCP to the Regent of Deli Serdang Regency by attaching the form filled in with administrative and technical requirements, so that on June 6, 2011 BCP Number 503,648 / 3790 / Bgkep was submitted to the applicant with the administrative forms and technical requirements, so on June 6, 2011 BCP Number 503,648 / 3790 / Bgkep on behalf of Nurbaya Sianipar, but during the field inspection on August 5, 2011 during the construction, a violation or deviation of Building Permit (BCP) was found that did not match the specified size and was validated on BCP Number 503,648 / 3790 / Bg. In connection with the violation committed by the building owner, the building owner admitted his mistake and on August 6, 2011 intended to dismantle the building himself which was not in accordance with the building permit No. 503,648 / 3790 / Bg witnessed by the Civil Service Police Task Force (Satpol PP) Deli Serdang Regency, the Satpol PP immediately submitted a Decree of the Deli Serdang Regent Number 503,648 / 5456 on August 15, 2011 regarding the revocation of building permit Number 503,648 / 3790 / Bg which had previously been owned by the Plaintiff, the plaintiff felt objected to the issuance of the Letter of Construction the decision to cancel the BCP, so on August 26, 2011 Nurbaya Sianipar sued the Regent of Deli Serdang Regency with the object of a lawsuit in the State Administration dispute, namely the Decree of the Regent of Deli Serdang Number: 503,648 / 5456 dated August 15, 2011 concerning the revocation of building permits ${ }^{13}$ Because of the Deli Serdang Regent Decree regarding the Revocation of Building Permit caused losses and injustice to the Plaintiff. The Defendant's answer at that time that the holder of a building permit had violated the provisions of the permit to build a building that had been determined in accordance with the request submitted by the Plaintiff himself. And there is no good faith on the notification that has been delivered by the Defendant. But related to the examination in dispute Decision No. 30 / B / 2012 / PT.TUN.Mdn The Assembly did not find any deviations in the implementation of the process requirements to obtain a building permit (BCP) the applicant had completed all the specified requirements in accordance with the Regional Regulation (Perda) in Deli Serdang Regency. ${ }^{14}$ So that the Medan State Administrative Court gave a ruling No. 72 / G / 2011 / PTUN-MDN dated 19 December 2011, the ruling as follows: grant the plaintiff's claim in full, declare that the Decree of Deli Serdang Regent No. 503,648 / 5456 dated 15 August 2011 concerning the Revocation of Building Permit in the name of Nurbaya Sianipar, obliges the Defendant to Decree the Regent of Deli Serdang Number: 503,648 / 5456 dated 15 August 2011 concerning Revocation of Building Permit on behalf of Nurbaya Sianipar, obliging the Defendant namely the Deli Serdang regent to revoke his decision with number: 503,648 / 5456 on August 15, and charge the defendant to pay the case fee and be strengthened by the Decree of the Medan State Administrative Court No. 30 / B / 2012 / PT.TUN.MDn affirmed Medan Administrative Court Decision No. 72 / G / 2011 / PTUN-Mdn dated March 14, 2012.

Judge's consideration is one of the most important aspects in determining the realization of the value of a judge's decision that contains justice and contains legal certainty, in addition it contains benefits for the parties concerned so that the judge's consideration must be addressed carefully, well and carefully. If the judge's considerations are not examined properly and careful then the judge's decision derived from the judge's consideration will be overturned by the High Court / Supreme Court. Judge's consideration of the decision number 72 / G / 2011 / PTUN-MDn and decision number 30 / B / 2012PT.TUN.MDn by looking at the facts in the field it can be said that the procedure has been in accordance with the laws and regulations that are related to the decision and in accordance with the general principles of good governance as stipulated in Article 55 of Law Number 5 of 1986 concerning State Administrative Court. ${ }^{15}$ The Judge in giving consideration and evaluation to the procedure for issuing the decision letter of the object of the dispute. The Panel of Judges will first cite a number of provisions guided by the Regional Regulation of Deli Serdang District Number 14 of 2006 concerning the Permit to Establish Buildings in Deli Serdang Regency and guided by Law Number 28 of 2002 Concerning Buildings and Law Number 51 of 2009 concerning amendments to Law of the Republic of Indonesia number 9 of 2004 and Law Number 5 of 1986 concerning State Administrative Court. The Judge's Judgment was carried out in accordance with the provisions contained in all regulations and laws relating to the case of revocation of building permits carried out by the Regent of Deli Serdang Regency. Because Nurabaya Sianipar as the BCP applicant at the time of submitting the application has fulfilled all the requirements as referred to in

\footnotetext{
${ }^{13}$ Decision No. 72 / G / 2011 / PTUN.MDN, page. 4

14 Decision number 30 / B / 2012 / PT.TUN.Mdn, Permit for Establishing a Building That Has Been Published

15 "A claim can only be filed within a period of ninety days from the date of receipt or announcement of the Decree of the State Administration Agency or Officer"
} 
the provisions of Article 8 paragraph (1) of Law Number 28 Year 2002 concerning Buildings. ${ }^{16}$ Therefore, the Deli Serdang Regency Government at the time of issuing the proposed BCP was first considered to have carried out its duties in accordance with the principle of good governance governing building construction permits because Nurabaya Sianipar as the BCP applicant had carried out procedures and all requirements based on the provisions of the applicable laws and regulations.

\subsection{Legal Protection of Consumers as a Result of the Cancellation of Building Permit (BCP) Which Is One of the Conditions for Making Purchase Binding Agreement (PBA) between Developer and Consumer}

Law Number 20 of 2011 concerning Flats includes detailed requirements before the developer engages in marketing activities as well as a binding sale and purchase agreement (PBA). In Article 42 it is stated, before developing the marketing must fulfill five requirements, namely: Principle Permit / Location Permit / Land Use Appointment Certificate (SIPPT) from the relevant agency. Site Plan, made by the developer with the approval of the local regional government which contains the land plan to be built as well as designation and shape. Certainty of Ownership Status, and Building Permit (BCP), the application for Building Permit is submitted to the Local Government Urban Development Supervision Service (SDPKK), Building Permit (IPB) is given by the local government after the building is completed.

Article 1 number 19 Medan City Regional Regulation Number 5 of 2012 Concerning Building Permit Levy it is stated that the Building Permit, hereinafter abbreviated as BCP is a permit granted by the regional government except for special function buildings by the Government to building owners to build new buildings, change / repair / rehabilitation / renovation, expand, reduce, and / or maintain buildings, and / or restore in order to preserve the building in accordance with applicable administrative and technical requirements.

Medan Mayor Regulation Number 41 Year 2012 Concerning Technical Instructions for Regional Regulation Number 5 Year 2012 Building Permit Levy, namely: Article 9 paragraph (1) which reads: Every individual or body that constructs buildings in a region must obtain a Building Establish License (BCP) for building construction assistance from the Regional Government. Article 9 paragraph (2) which reads: Building Permit (BCP) is granted to areas whose land designation has been determined in accordance with the city spatial plan and technically complies with the city spatial plan and complies with building reliability requirements The granting of a building permit (BCP) must also have a correlation with the regulation on spatial planning, Law Number 26 of 2007, Article 26 and Article 28 stipulates that the City Spatial Planning (RTRW) of the City becomes the basis for issuing permits. construction site and land administration. But with the cancellation of one of the permits, namely Building Permit (BCP) which has been owned by PT. Sinar Permata Deli Podomoro based on the Supreme Court Decree Number 274 K / TUN / 2016, then all PBA related to the requirement to have an BCP will be null and void by law, it appears that this PTUN Decision does not protect consumers, because it is more directed to the State Administration. In the Consumer Protection Act, consumer rights can be protected, it can be seen in the provisions of Article 19 paragraph (1) which specifies that the business actor is responsible for providing compensation for damage to the pollution and / or loss of consumers due to consuming goods and / or services produced or traded. In addition, according to the provisions of Article 28 of the UUPK that the proof of the existence of an element of error in the claim for compensation as intended in Article 19, Article 22 and Article 23 is the burden and responsibility of the business actor.

Legal protection for consumers can be done through various provisions regulated in Law Number 8 of 1999 concerning Consumer Protection (UUPK). Based on the provisions in the UUPK that defines consumers are all users of goods and / or services available in the community, both for the benefit of themselves, families, other people and other living things and not for trading. Whereas Business Actors are every individual or business entity, both in the form of legal entity or non-legal entity established and domiciled or carrying out activities within the jurisdiction of the Republic of Indonesia, both individually and jointly through agreements to carry out business activities in various economic fields. Seeing from the understanding of consumers and business actors above, then every person who makes a home purchase transaction either in credit or cash can be categorized as a consumer, while the developer (developer) who does business in the housing sector can be categorized as a business actor. If one party experiences a loss, the party causing the loss must be held responsible.

Problems that occur when the BCP is canceled based on the Decision of the Supreme Court Number 274 K / TUN / 2016, causing the business activities to cease and the agreement that has been agreed to become null and

\footnotetext{
16 "Every Building must meet administrative requirements which include: Status of land rights, and / or utilization permits from holders of land rights; Status of building ownership; Permit to build a building, in accordance with applicable laws and regulations.
} 
void. events that may occur and have not yet happened, either by suspending the engagement of the engagement until the event occurs, or by canceling the engagement, depending on whether or not the event occurred ", this is the basis of the agreement made by prospective housing consumers and developers, namely PBA which is a conditional engagement, among others the repayment has not been made by the Consumer Party as a buyer or Certificate of land which is used as the object of buying and selling is still in process at the authorized agency, including its licensing.

Pursuant to the provisions of the aforementioned Article requires that an agreement arising from PBA made between the Developer and the consumer can be canceled by agreement of the parties as a result of the cancellation of the BCP based on the Decision of the Supreme Court Number 274 K / TUN / 2016. When the PBA is canceled, all consumer rights that have been surrendered to the developer should be returned in full. However, based on the discussion in the previous sub-chapter, it is known that due to the cancellation of the BCP, the PBA becomes null and void.

As a result of the PBA which is null and void due to the loss suffered by the Consumer, then based on the provisions of Article 46 paragraph (1) point a of the UUPK, the article states that a disadvantaged consumer or his heir may request accountability from the business actor. So based on the provisions of this Article, both consumers and their heirs who suffer losses due to PBA that are null and void by law can hold the developer responsible as a business actor. Further provisions in point $\mathrm{b}$ of the same Article state that a group of consumers who have the same interests can ask accountability from business actors (class action). This provision can be used as a basis for consumers as home buyers to jointly make compensation claims to developers for losses incurred due to PBA that are null and void.

Based on the discussion of the results of the above research with respect to consumer protection, it appears that one of the consumer's rights to obtain compensation and / or replacement if the goods and / or services received are not in accordance with the agreement or not as they should still not be realized by the business actor in this is PT. Sinar Permata Deli Podomoro as the seller, so that the Podomoro Deli City housing consumer can settle the dispute claim for compensation under the provisions of the UUPK who are familiar with two types of institutions in settling compensation disputes between business actors and consumers based on voluntary choice, according to Article 45 paragraph ( 2) juncto Article 49 paragraph (1) UUPK, namely: Litigation and Non Litigation. In the explanation of Article 45 paragraph (2) it is stated that the settlement of consumer disputes as referred to in this paragraph does not rule out the possibility of a peaceful settlement by the parties to the dispute. At each stage, efforts are made to use a peaceful settlement by both parties to the dispute without going through a court or consumer dispute resolution body and not in conflict with this Law.

Settlement of disputes between business actors and consumers outside the court (through BPSK) based on the provisions of Article 47 of the UUPK, aims to reach an agreement on the form and amount of compensation and / or certain actions to ensure that there will be no loss suffered by consumers, consequently the provisions " null and void "against PBA that has been made between PT. Sinar Permata Deli Podomoro as the seller with the consumer as the buyer requires that both return to the original concession as if there had never been a sale and purchase, from PT. Sinar Permata Deli Podomoro returns all money received from consumers plus abstract losses as stipulated in the UUPK as well as consumers must return land and buildings to their original state. However, if the dispute resolution effort outside the court (through BPSK) is declared unsuccessful by either party, PT. Sinar Permata Deli Podomoro or the consumer or both based on the provisions of Article 45 paragraph (4) UUPK). then a claim for compensation through a court can be carried out.

Further provisions in Article 46 paragraph (1) point c similarly state that non-governmental consumer protection institutions that meet the requirements, namely in the form of legal entities or foundations, in the articles of association expressly state that the purpose of the establishment of the organization is in the interests of consumer protection and has carrying out activities in accordance with its articles of association, may hold businesses accountable. Even this can be an alternative for home buyer consumers to make complaints about problems and losses suffered due to canceled BCP and causing PBA null and void.

Article 46 paragraph (2) states that a lawsuit filed by a group of consumers, non-governmental consumer protection institutions, or the government as referred to in paragraph (1) letter b, letter c, and letter d, shall be submitted to the general court. From the above statement, the UUPK recognizes that class action or class action must be filed by consumers who are truly disadvantaged and can be proven legally, one of which is evidence of transactions in this case the existence of PBA between the Developer as the seller and the consumer as the buyer.

Therefore, based on the provisions of the aforementioned Article, it gives authority to several legal subjects to hold developers responsible as business actors, among others by: 
a. The injured consumer or his heir personally;

b. A group of consumers who have the same interests (class action) or hold accountable business actors in groups (Group lawsuit);

c. Non-governmental consumer protection institutions that meet the requirements as regulated in Article 46 paragraph (1) letter $\mathrm{c}$ of the UUPK;

d. The government and / or related agencies if the result of the utilization / consumption of the product results in large material losses and / or not a small number of victims (Article 46 paragraph (1) letter d of UUPK).

One way to carry out accountability demands made by consumers as a result of the Supreme Court Decree Number 274 K / TUN / 2016 which canceled the Building Construction Permit (BCP) made by PT. Sinar Permata Deli Podomoro and caused the PBA (Purchase Binding Agreement) related to the requirement to have the BCP become null and void, then the PBA was considered to have never existed and had no legal consequences from the start. If the decision of the Supreme Court (MA) has permanent legal force, then the decision can only be executed. Thus, all the obligations of consumers who have given a sum of money to the developer must be returned completely from the Developer to the Consumer, this is intended in order to return to its original state like there was never buying and selling.

If the sum of money that should have been returned to the rights of the Consumer is not returned, then the consumer can take legal action to submit to the Local District Court to cancel the PBA and submit the request for execution. This is regulated in the provisions of Article 196 of Herzien Inlandsch Regulations ("HIR") which confirms that: "If the defeated party is unwilling or negligent to fulfill the contents of the decision peacefully, then the winning party submits the request, both verbally, and by a letter, to the head of the district court mentioned in the first paragraph of Article 195, in order to carry out the decision, the Chairperson ordered the defeated party to be warned and warned him to fulfill the decision within the time determined by the chairman, which lasts eight days. "

\section{Conclusions}

Based on the results of research and discussion that has been done, the following conclusions can be given:

a. Building Construction Permit (BCP) which is one of the absolute requirements to make a PBA is one of the natural elements inside, because even though it is not explicitly stated in one of the PBA clauses, it is expressly regulated and required in several statutory provisions. So as a result of the cancellation of the BCP based on the Decision of the Supreme Court Number 274 K / TUN / 2016, all PBA related to the BCP which should be an integral part of the land and building shall be null and void due to violation of the objective elements / conditions of the legal agreement as regulated in the provisions of Article 1320 of the Civil Code, namely violations of the provisions of "a certain thing" and the provisions of "lawful causes".

b. Legal protection for Podomoro Deli City Housing Consumers against losses incurred as a result of PBA that is null and void by law can be done through several provisions in the UUPK, including Article 46 of the UUPK which determines that consumers who are disadvantaged or their heirs can hold responsibility from business actors, both individually and jointly with other consumers (class action) or through consumer protection agencies, to make demands for accountability and lawsuits to the developer as a business actor.

\section{Suggestions}

a. Losses experienced by consumers due to negligence in the application process to the issuance of Building Permit (BCP) in Podomoro City Deli housing can be minimized, one of which is by a Notary Public General during and before the sale and purchase transaction between the developer and the consumer as outlined in Binding Agreement of Sale and Purchase (PBA), this is in accordance with the provisions of Article 15 paragraph 2 letter $\mathrm{f}$ which confirms that the Notary has the authority to provide legal counseling to his client in connection with the deed drawn up, therefore the Notary in making the PBA should explain in detail all aspects relating to the purchase of housing units including the completeness of licenses to consumers as clients in addition to the general explanation that applies in making authentic deeds, so as to create the principle of balance and fairness in the buying and selling process as outlined in the PBA.

b. Did not rule out the possibility of consumers who suffered losses when going to buy housing units Podomoro City Deli did not know very well about the truth of the material regarding all housing permits, so that as a result of the cancellation of the BCP for housing there was a loss experienced by consumers, therefore the application of strict sanctions Podomoro City Deli developers should be given in the form of administrative sanctions and compensation to consumers as stipulated in the applicable laws and regulations, this is intended to be made a 
lesson to all developers who will carry out marketing and sales of housing to potential consumers (buyers). This can be used as an alternative legal protection in addition to various other legal remedies in the event of an act of default / negligence by the developer resulting in harm to the consumer. The legal remedies procedure referred to is consensus agreement between developers and consumers, complaints to BPSK or lawsuits through litigation.

\section{References}

Data from www.rei.or.id, Pre Project Selling, accessed on March 5, 2018, at 12.00 WIB.

Decision No. 72 / G / 2011 / PTUN.MDN.

Decision number 30 / B / 2012 / PT.TUN.Mdn, Permit to Establish a Building That Has Been Published.

Law Number 1 of 2011 concerning Housing and Settlement Areas.

Marsono. (1995). Laws and Regulations in the Field of Housing and Settlements. Jakarta, Djambat.

Regional Regulation of Deli Serdang Regency Number 14 Year 2006, Regarding Permit to Establish Buildings in Deli Serdang Regency.

Regulation of the Minister of Public Works and Public Housing of the Republic of Indonesia, Number 24 / PRT / M / 2007 Regarding Technical Guidelines for Establishing Buildings.

Republic of Indonesia Government Regulation Number 27 of 1999 concerning Environmental Impact Analysis.

Republic of Indonesia Minister of Home Affairs Regulation, Regulation Number 32 Year 2010, Regarding Guidelines for Granting Construction Permits.

Soekanto, S., \& Mamudji, S. (2001). Normative Legal Research: A Brief Review. Jakarta, Raja Grafindo Persada. Waluyo, B. (1991). Legal Research in Practice. Jakarta, Sinar Grafika.

\section{Copyrights}

Copyright for this article is retained by the author(s), with first publication rights granted to the journal.

This is an open-access article distributed under the terms and conditions of the Creative Commons Attribution license (http://creativecommons.org/licenses/by/4.0/). 